\title{
Agronomic Performance for Tuber Characters in Winged Bean [Psophocarpus tetragonolobus (L.) DC.]
}

\author{
Achal Kant ${ }^{1^{*}}$, R. Nandan ${ }^{2}$ and P. C. Kole ${ }^{3}$ \\ ${ }^{1,2}$ Dept. of Genetics and Plant Breeding, Institute of Agricultural Sciences, BHU, Varanasi, U.P. (221 005), India \\ ${ }^{3}$ Dept. of Genetics and Plant Breeding and Crop Physiology, Institute of Agriculture, Visva-Bharati, Sriniketan W.B. (731 236), India
}

\section{Corresponding Author}

Achal Kant

e-mail: 786achalgupta90@gmail.com

\author{
Article History \\ Article ID: IJEP0242 \\ Received in $27^{\text {th }}$ January, 2018 \\ Received in revised form $7^{\text {th }}$ March, 2018 \\ Accepted in final form $18^{\text {th }}$ March, 2018
}

\begin{abstract}
The present investigation was carried out to identify the tuber producing genotypes from a pool of 27 genotypes of winged bean. The experiments were conducted at Vegetable Research Farm of Banaras Hindu University, Varanasi, Uttar Pradesh during kharif season of 2014 and 2015. Among 27 genotypes, 22 genotypes were tuberous roots producing, while rest five genotypes were non-tuberous. These tubers forming 22 genotypes were further grown for evaluation of their performance in next kharif season of 2015 . Based on different agronomic characters, the accessions RWB-15 recorded the highest values for tuber yield plant ${ }^{-1}(\mathrm{~g})$, tuber length (cm), tuber dry matter (\%) and total sugar content $\left(\mathrm{g} \mathrm{g}^{-1}\right)$ in tuber with moderate values for tuber breadth $(\mathrm{cm}), 100$ seeds weight $(\mathrm{g})$ and tuber crude protein $(\%)$, followed by Ambika-13-4, RMDWB-1, Ambika WB -11-2 and IC-178292 which appeared promising for different tuber characters. Therefore, RWB-15 along with the above four accessions could be tested under different agronomic practices for commercial production and human consumption of this tuber producing legume.
\end{abstract}

Keywords: Winged bean, genotypes, tuberous roots, tuber yield

\section{Introduction}

Winged bean [Psophocarpus tetragonolobus (L.) DC.] is an under-utilized plant which has a wide genetic potential, to be utilized as a source of quality food and forage. Winged bean is a protein rich multipurpose legume. It is consumed as pods, seeds, flowers and also tuberous roots because of their great nutritional values. Winged bean has been regarded as "One species supermarket" because practically all of the plant parts are edible (Bhattacharyya, 2016; Wilson et al., 2006; Wilson, 1984). The tubers, young pods, seeds, leaves, flowers and shoot are rich in protein, amino acids, oils, vitamins and minerals (Claydon, 1978; Hettiarachchy and Kantha, 1982).

An interesting feature of the winged bean is that it produces tuberous roots. Its tubers contain high crude protein as well as carbohydrate (on dry basis) of $3-15 \%$ and $27.2-30.5 \%$, respectively (Burkill, 1906; NAS, 1981; Chandel, 1984). The tubers are said to have a pleasant and slightly sweet taste, ivory white flesh and firm texture resembling an apple (NAS, 1975a; 1975b). Tuber development is a genetic character and is fully attained at ten to twelve months of growth (Karikari, 1978). Non-availability of suitable tuber producing genotypes and narrow genetic base in winged bean restrict its growing on limited parts of the world.

In humid sub-tropical parts of north-eastern region of India i.e. Tripura, Manipur, Mizoram including adjoining areas of Assam and sporadic occurrence in the Western Ghats, winged bean only known for their green pods and seeds.

Studies on genetics and breeding of winged bean are limited. Hitherto, the genetic diversity of the crop remains largely unexploited. Winged bean received no appreciable research effort, especially for its genetic improvement. Therefore, realizing the importance and need of this underexploited grain legume, experiments were conducted for evaluation of performance of some germplasm for tuber characters.

\section{Materials and Methods}

The present investigation was carried out at Vegetable Research Farm of Banaras Hindu University, Varanasi, Uttar Pradesh during kharif season of 2014 and 2015. During kharif 2014 season, 27 diverse winged bean genotypes were grown for judging their potential for tuber growth.

Based on observations 22 genotypes with tuberous growth out of 27 were selected for evaluation in kharif season of 2015. All selected 22 genotypes were grown in a Randomized 
block design with three replications during kharif season 2015. Each plot consisted of one row of $5 \mathrm{~m}$ length with row to row and plant to plant distance of $75 \mathrm{~cm}$ and $50 \mathrm{~cm}$, respectively. Plants were subjected to vegetative pruning and reproductive pruning to promote good tuber growth. Tuber harvesting was done, when the all plant parts dried up to around $80 \%$.

Crude protein (\%), total sugar Content $\left(\mathrm{g} \mathrm{g}^{-1}\right)$ and Dry Matter (\%) in tuber were estimated by using Micro- Kjeldahl, Anthrone and AOAC methods, respectively.

Observations were recorded on five pruned plants for Tuber yield plant ${ }^{-1}(\mathrm{~g})$, Tuber length (cm.), Tuber breadth (cm.), Tuber dry matter (\%), Tuber crude protein (\%), Total sugar content in tuber $\left(\mathrm{g} \mathrm{g}^{-1}\right)$ and 100 seed weight $(\mathrm{g})$.

\section{Results and Discussion}

Among 27 genotypes, only 22 genotypes were tuber producing, while rest five genotypes were non-tuberous (Table 1).
The result of 22 winged bean genotypes showed the range of mean from $12.95 \mathrm{~cm}$. in EC-15018 to $18.89 \mathrm{~cm}$. in RWB-15 with general mean $15.88 \mathrm{~cm}$. for tuber length, $0.59 \mathrm{~cm}$. in Ambika WB -13-1 to $1.55 \mathrm{~cm}$. in Ambika-13-4 with general mean 1.13 $\mathrm{cm}$. for tuber breadth, $20.19 \%$ in RWB-13 to $35.89 \%$ in RWB15 with general mean $27.90 \%$ for tuber dry matter $\%, 0.280$ $\mathrm{g} \mathrm{g}^{-1}$ in RWB-13 to $0.518 \mathrm{~g} \mathrm{~g}^{-1}$ in RWB-15 with general mean $0.379 \mathrm{~g} \mathrm{~g}^{-1}$ for total sugar content in tuber, 5.05\% in Ambika WB-13-1 to $7.26 \%$ in IC-26904 with general mean $6.20 \%$ for tuber crude protein \%, $18.19 \mathrm{~g}$ in RMDWB-1 to $37.19 \mathrm{~g}$ in IC38683 with general mean $25.76 \mathrm{~g}$ for 100 seed weight, 12.65 $\mathrm{g}$ in EC-178309 to $47.95 \mathrm{~g}$ in RWB-15 with general mean 25.45 $\mathrm{g}$ for tuber yield plant ${ }^{-1}$.

The upper limit of range for various traits under study was exhibited by different accessions. However, accessions exhibiting highest values for more than one characters are RWB-15 for tuber yield plant ${ }^{-1}$ (47.95 g), tuber length (18.89 $\mathrm{cm})$, tuber dry matter (35.89\%), total sugar content in tuber $\left(0.52 \mathrm{~g} \mathrm{~g}^{-1}\right)$ with moderate values for tuber breadth (1.30

Table 1: Tuberous (22) and non-tuberous (5) root genotypes of winged bean

\begin{tabular}{llllc}
\hline & \multicolumn{2}{c}{ Tuberous root genotypes } & & Non-tuberous root genotypes \\
\cline { 1 - 2 } RWB-15 & Ambika-13-4 & RMDWB-1 & Ambika WB-11-2 & Ambika WB-11-2 (white) \\
IC-178292 & IC-26904 & AKWB-1 & IC-38683 & EC-172600 \\
Ambika WB 11-1 & Ambika-13-5 & Ambika WB-13-6 & EC-15018 & EC-178279 \\
EC-13084 & BHW-1 & Ambika WB-11-3 & RWB-2 & EC-178295 \\
RWB-16 & EC-178289 & Ambika WB-13-1 & EC-27884 & IC-26945 \\
RWB-13 & EC-178309 & & & \\
\hline
\end{tabular}

$\mathrm{cm}$ ), 100 seed weight ( $25.68 \mathrm{~g}$ ) and tuber crude protein (5.63 $\%)$, followed by Ambika-13-4, RMDWB-1, Ambika WB -11-2 and IC-178292 which appeared promising for different tuber characters (Table 2).
The accessions RWB- 15 recorded highest mean performance for tuber yield plant ${ }^{-1}$ followed by Ambika-13-4, RMDWB-1, Ambika WB-11-2 and IC-178292 (Figure 1). Mohamad et al. (2005) also reported high tuber yield of winged bean.

\begin{tabular}{|c|c|c|c|c|c|c|c|c|}
\hline $\begin{array}{l}\text { SI. } \\
\text { No. }\end{array}$ & Genotypes & $\begin{array}{c}\text { Tuber } \\
\text { length }(\mathrm{cm})\end{array}$ & $\begin{array}{l}\text { Tuber } \\
\text { breadth } \\
\text { (cm) }\end{array}$ & $\begin{array}{l}\text { Tuber dry } \\
\text { matter \% }\end{array}$ & $\begin{array}{l}\text { Total sugar } \\
\text { content }(\mathrm{g} \\
\left.\mathrm{g}^{-1}\right) \text { in tuber }\end{array}$ & $\begin{array}{c}\text { Tuber crude } \\
\text { protein } \%\end{array}$ & $\begin{array}{l}100 \text { seed } \\
\text { weight }(\mathrm{g})\end{array}$ & $\begin{array}{c}\text { Tuber } \\
\text { yield } \\
\text { plant }^{-1}(\mathrm{~g})\end{array}$ \\
\hline 1. & RWB-15 & 18.89 & 1.30 & 35.89 & 0.518 & 5.63 & 25.68 & 47.96 \\
\hline 2. & Ambika -13-4 & 16.01 & 1.55 & 27.00 & 0.320 & 5.74 & 24.00 & 40.13 \\
\hline 3. & RMDWB-1 & 18.37 & 1.28 & 34.04 & 0.490 & 5.36 & 18.19 & 35.54 \\
\hline 4. & Ambika WB-11-2 & 17.72 & 1.01 & 29.87 & 0.461 & 6.32 & 26.04 & 34.80 \\
\hline 5. & IC-178292 & 16.19 & 1.30 & 30.37 & 0.483 & 5.75 & 22.42 & 34.15 \\
\hline 6. & IC-26904 & 15.86 & 0.90 & 28.52 & 0.444 & 7.26 & 23.67 & 31.48 \\
\hline 7. & AKWB-1 & 16.79 & 1.37 & 31.61 & 0.350 & 6.30 & 25.07 & 30.54 \\
\hline 8. & IC-38683 & 15.86 & 1.28 & 27.96 & 0.371 & 5.82 & 37.19 & 26.78 \\
\hline 9. & Ambika WB-11-1 & 15.82 & 0.87 & 27.47 & 0.406 & 6.71 & 27.80 & 25.22 \\
\hline 10. & Ambika -13-5 & 14.91 & 1.19 & 22.53 & 0.355 & 5.72 & 29.33 & 23.83 \\
\hline 11. & Ambika WB-13-6 & 14.84 & 1.08 & 30.86 & 0.328 & 6.06 & 35.67 & 23.49 \\
\hline
\end{tabular}




\begin{tabular}{|c|c|c|c|c|c|c|c|c|}
\hline SI. No. & Genotypes & $\begin{array}{c}\text { Tuber } \\
\text { length }(\mathrm{cm})\end{array}$ & $\begin{array}{l}\text { Tuber } \\
\text { breadth } \\
\text { (cm) }\end{array}$ & $\begin{array}{l}\text { Tu b e r } \\
\text { dry mat- } \\
\text { ter } \%\end{array}$ & $\begin{array}{l}\text { Total sugar } \\
\text { content }(\mathrm{g} \\
\mathrm{g}^{-1} \text { ) in tuber }\end{array}$ & $\begin{array}{c}\text { Tuber crude } \\
\text { protein } \%\end{array}$ & $\begin{array}{l}100 \text { seed } \\
\text { weight }(\mathrm{g})\end{array}$ & $\begin{array}{c}\text { Tuber yield } \\
\text { plant }^{-1}(\mathrm{~g})\end{array}$ \\
\hline 12. & EC-15018 & 12.95 & 1.31 & 28.28 & 0.483 & 6.12 & 26.00 & 23.46 \\
\hline 13. & EC-13084 & 14.71 & 1.28 & 22.53 & 0.386 & 6.08 & 19.00 & 22.57 \\
\hline 14. & BHW-1 & 16.05 & 1.14 & 33.15 & 0.335 & 6.40 & 22.38 & 21.33 \\
\hline 15. & Ambika WB-11-3 & 15.87 & 1.09 & 24.87 & 0.355 & 7.05 & 25.19 & 20.50 \\
\hline 16. & RWB-2 & 17.83 & 1.12 & 30.74 & 0.287 & 6.09 & 22.00 & 20.47 \\
\hline 17. & RWB-16 & 15.69 & 1.30 & 24.38 & 0.320 & 7.12 & 25.33 & 17.95 \\
\hline 18. & EC-178289 & 16.65 & 1.02 & 24.05 & 0.304 & 6.74 & 27.37 & 17.81 \\
\hline 19. & Ambika WB-13-1 & 16.75 & 0.59 & 28.79 & 0.344 & 5.05 & 22.67 & 17.64 \\
\hline 20. & EC-27884 & 14.62 & 0.99 & 30.04 & 0.354 & 6.16 & 24.67 & 16.22 \\
\hline 21. & RWB-13 & 13.68 & 1.05 & 20.19 & 0.280 & 6.66 & 28.33 & 15.46 \\
\hline 22. & EC-178309 & 13.38 & 0.75 & 20.70 & 0.361 & 6.28 & 28.73 & 12.65 \\
\hline Range & Minimum & 12.95 & 0.59 & 20.19 & 0.280 & 5.05 & 18.19 & 12.65 \\
\hline & Maximum & 18.89 & 1.55 & 35.89 & 0.518 & 7.26 & 37.19 & 47.95 \\
\hline \multicolumn{2}{|c|}{ General mean } & 15.88 & 1.13 & 27.90 & 0.379 & 6.20 & 25.76 & 25.45 \\
\hline
\end{tabular}

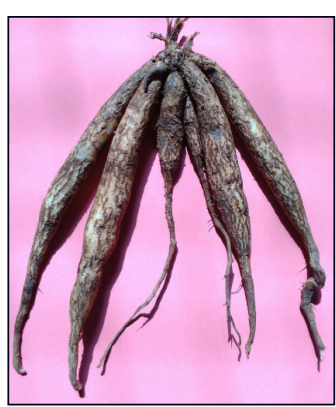

RWB-15

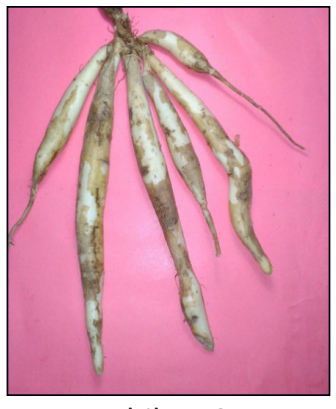

Ambika-13-4

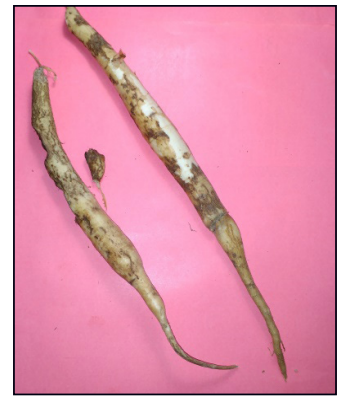

RMDWB-1

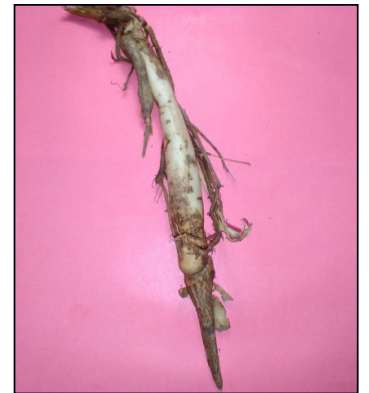

AmbikaWB-11-2

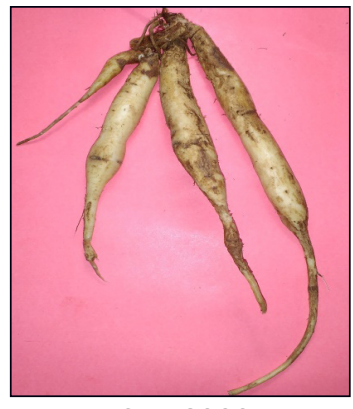

IC-178292

Figure 1: Top five high tuber yielding genotypes of winged bean

\section{Conclusion}

The winged bean genotypes showed a wide range of variation for tuber yield plant ${ }^{-1}$ followed by others remaining characters studied. The results indicate that there is ample scope for selection of promising genotypes from present set of accessions for tuber yield improvement programme. The variability in this germplasm pool could be utilized in recombination breeding programme for accumulation of desirable traits in a single genotype.

\section{References}

Bhattacharyya, B., 2016. Golden Greens: The Amazing World of Plants.The Energy and Resources Institute (TERI), 128.

Burkill, I.H., 1906. Psophocarpus tetragonolobus (Goa Bean.) Goa beans in India. The Agricultural Ledger 4, 101-114.

Chandel, K.P.S., Pant, K.C., 1984. Winged bean in India, NBPGR Sci. Monogr. No. 8, 1-30.

Claydon, 1978. The role of the winged bean in human nutrition. Workshop/Seminar on the Development of the Potential of the Winged Bean. Los Banos.

Hettiarachchy, N.S., Sri Kantha, S., 1982. Nutritive value of winged bean, Psophocarpus tetragonolobus. Nutrisyon 7, 40-51.

Karikari, S.K., 1978. The Potential of the Winged Bean (Psophocarpus tetragonolobus (L.) DC as a Root Crop. International Symposium on Tropical Root and Tuber Crops; 135-145.

Mohamad, A., Madalageri, M.D., Mulge, R., 2005. Evaluation of winged bean [Psophocarpus tetragonolobus (L.) DC.] accessions for growth and yield characters. Research on Crops 6(2), 270-273.

NAS, 1981. The Winged Bean: A High-Protein Crop for the Tropics. $2^{\text {nd }}$ Ed. National Academy of Sciences. National Academy Press, Washington, D.C.

NAS, 1975a. The Winged Bean. A high-protein crop for the tropics. National Academy of Sciences, Washington, D. C, 43. 
NAS, 1975b. Underexploited tropical plants with promising economic value. National Academy of Sciences, Washington D.C, 56.

Wilson, E.O., 1984. Biophilia. Harvard University Press, 132.
Wilson, E.O., Wilson, E.O., Zoologist, B., Wilson, E.O., Zoologiste, B., Wilson, E.O., 2006. Nature revealed: selected writings, 1949-2006. Johns Hopkins University Press, 541. 